\title{
Pemanfaatan Google Classroom Sebagai Media Pembelajaran Di Masa Pandemi Covid-19
}

\author{
Rini Atikah" ${ }^{\# 1}$, Rani Titik Prihatin" ${ }^{\# 2}$,Herni hernayati\# ${ }^{\# 3}$ Jajang Misbah $^{\# 4}$ \\ \#Program Studi Teknologi Pendidikan, Pascasarjana Institut Pendidikan Indonesia Garut \\ Jl. Terusan Pahlawan No.32, Sukagalih, Kec. Tarogong Kidul, Kabupaten Garut \\ 1atikahriniegmail.com
}

\begin{abstract}
This research emphasizes on the use of learning using google classroom to have a positive impact, which can be seen from student learning outcomes which are increasing every day through assignments and quizzes. Students' perceptions about subjects carried out online are using the Google classroom application, namely students feel happy using Google classroom because it is easy and teachers / educators are not burdensome by giving many assignments, Google classroom is flexible, which is easy to access anywhere and anytime, is constrained by internet access from the absence of data networks or smartphones that are used to support all students for the implementation of e-learning. The research method used is the literature study method, which is a series of activities related to the method of collecting library data, reading and taking notes, and managing research materials.
\end{abstract}

Keyword: google classroom, utilization, online learning media.

Abstrak - Penelitian ini menekankan pada pemanfaatan pembelajaran dengan menggunakan google classroom memiliki dampak yang positif dapat dilihat dari hasil belajar siswa yang semakin meningkat setiap harinya melalui tugas dan kuis. Persepsi siswa mengenai mata pelajaran yang dilakukan melalui daring menggunakan aplikasi Google classroom yaitu siswa merasa senang menggunakan Google classroom karena mudah dan guru/pendidik tidak memberatkan dengan memberikan banyak tugas, Google classroom bersifat fleksibel yaitu mudah di akses dimana saja dan kapan saja, terkendala akses internet dari tidak adanya jaringan data maupun smartphone yang digunakan sebagai pendukung semua siswa untuk pelaksanaan pembelajaran e-learning. Adapun metode penelitian yang digunakan adalah Metode studi literatur adalah serangkaian kegiatan yang berkenaan dengan metode pengumpulan data pustaka, membaca dan mencatat, serta mengelolah bahan penelitian

Kata kunci: google classroom, pemanfaatan, media pembelajaran daring.

\section{PENDAHULUAN}

Saat ini dunia dikejutkan dengan mewabahnya suatu penyakit yang disebabkan oleh sebuah virus yang bernama corona atau dikenal dengan istilah covid-19. Akibat adanya pandemi covid-19 ini, menyebabkan diterapkannya berbagai kebijakan untuk memutus mata rantai penyebaran virus covid- 19 tersebut. Social distancing menjadi pilihan berat bagi setiap negara dalam menerapkan kebijakan untuk pencegahan penyebaran covid-19, karena kebijakan ini berdampak negatif terhadap segala aspek kehidupan. [1]

Pada hakikatnya pembelajaran adalah proses untuk mengatur dan mengorganisasi seluruh lingkungan yang ada disekitar siswa sehingga dapat menumbuhkan dan mendorong siswa melakukan proses belajar [2]. Terdapat dua jenis pembelajaran yaitu pembelajaran konvensional dan daring. Menurut Djamarah, metode pembelajaran konvensional adalah metode pembelajaran tradisional atau disebut juga dengan metode ceramah, karena sejak dulu metode ini telah dipergunakan sebagai alat komunikasi lisan antara guru dengan anak didik dalam proses belajar dan pembelajaran [3]. Dalam pembelajaran sejarah metode konvensional ditandai dengan ceramah yang diiringi dengan penjelasan serta pembagian tugas dan latihan. Sedangkan pembelajaran daring adalah singkatan dari "dalam jaringan" sebagai pengganti kata online yang sering kita gunakan dalam kaitannya dengan teknologi internet. Seiring dengan perkembangan teknologi informasi dan komunikasi, maka muncul sistem pembelajaran baru, yaitu pembelajaran daring. Pembelajaran daring atau pembelajaran dalam jaringan adalah pembelajaran jarak jauh yang menggunakan internet dan beberapa teknologi sebagai media yang digunakan.

Untuk mendukung pembelajaran daring maka diperlukannya sebuah platform media sosial. Media sosial merupakan salah satu media dimana para penggunanya dapat mencari informasi, saling berkomunikasi dan menjalin pertemanan secara online. Seperti diketahui ragam media social, yakni salah satunya google classroom. Google Classroom memungkinkan kegiatan belajar mengajar menjadi lebih produktif dan bermakna dengan menyederhanakan tugas, meningkatkan kolaborasi, dan 
membina komunikasi. Pengajar dapat membuat kelas, memberikan tugas, mengirim masukan, dan melihat semuanya di satu tempat.

Di Indonesia pemerintah harus menutup sekolah dan universitas yang berada di wilayah yang terpapar Covid-19. Penutupan sekolah di Indonesia secara langsung akan berdampak terhadap proses pembelajaran disekolah. Guru dan siswa yang biasanya melakukan pembelajaran secara langsung dikelas, saat ini dipaksa harus berpindah ke dalam proses pembelajaran jarak jauh untuk menghindari terjadinya kerumunan sebagai langkah pencegahan penyebaran Covid19.

Berbagai problematika pendidikan di Indonesia cukup banyak, mulai dari masalah kurikulum, kualitas, kompetensi, bahkan kompetensi kepemimpinan baik itu dijajaran tingkat atas maupun tingkat bawah. Berbagai kasus keluhan-keluhan terjadi di lapangan, baik pimpinan sekolah maupun para pendidik yang menyayangkan dimensi kepemimpinan seperti soal manajemen, disiplin, birokrasi dan administrasi yang amburadul. Kemudian yang tidak kalah pentingnya juga soal kepemimpinan di sekolah turut berperan mewarnai wajah penyelenggaraan dunia pendidikan serta memperlebar kesenjangan dan konflik internal para pendidik [4]

Dari permasalahan inilah penulis mencoba mencari solusinya dengan berbagai usaha dan strategi yang dilakukan untuk mengembangkan pemikiran siswa yang beraneka ragam, ditambah lagi pada masa pandemi sekarang yang mengharuskan siswa untuk belajar dirumah, maka kehadiran google classroom menjadi salah satu solusi dengan berbagai permasalahan yang sedang dihadapi saat ini.

\section{Tinjauan Pustaka}

\section{A. Pembelajaran}

Belajar menurut Sudjana Nana, adalah suatu proses yang ditandai dengan adanya perubahan pada diri seseorang [5]. Belajar menurut Morgan, adalah perubahan perilaku yang bersifat permanen sebagai hasil dari pengalaman. Salah satu pertanda bahwa seseorang telah belajar sesuatu adalah adanya perubahan tingkah laku dalam dirinya [6].

Perubahan tingkah laku tersebut menyangkut baik perubahan yang bersifat pengetahuan (kognitif), keterampilan (psikomotor) maupun yang menyangkut nilai dan sikap (afektif). Belajar tidak hanya meliputi mata pelajaran, tetapi juga penguasaan, kebiasaan, persepsi, kesenangan, kompetensi, penyesuaian sosial, bermacammacam keterampilan, dan cita-cita [7].

\section{B. Konsep E-learning}

E-learning tersusun dari dua bagian, yaitu 'e' yang merupakan singkatan dari 'electronica' dan 'learning' yang berarti 'pembelajaran'. Jadi e-learning berarti pembelajaran dengan menggunakan jasa bantuan perangkat elektronika. Jadi dalam pelaksanaannya, e-learning menggunakan jasa audio, video atau perangkat komputer atau kombinasi dari ketiganya. Dengan kata lain e-learning adalah pembelajaran yang dalam pelaksanaannya didukung oleh jasa teknologi seperti telepon, audio, videotape, transmisi satelite atau komputer Sejalan dengan itu, Onno W. Purbo menjelaskan bahwa istilah "e" dalam e-learning adalah segala teknologi yang digunakan untuk mendukung usaha-usaha pengajaran lewat teknologi elektronik internet [8]. Internet, satelit, tape audio/video, tv interaktif, dan CD-ROM adalah sebagian dari media elektronik yang digunakan. Pengajaran boleh disampaikan pada waktu yang sama (synchronously) ataupun pada waktu yang berbeda (asynchronously). Secara lebih singkat william Horton mengemukakan bahwa e-learning merupakan kegiatan pembelajaran berbasis web (yang bisa diakses dari internet) [9]. Tidak jauh berbeda dengan itu Brown, 2000 dan Feasey, 2001 (dalam Kamarga, Hansiswany, 2001). Secara sederhana mengatakan bahwa elearning merupakan kegiatan pembelajaran yang memanfaatkan jaringan (internet, LAN, WAN) sebagai metodepenyampaian, interaksi, dan fasilitas yang didukung oleh berbagai bentuk layanan belajar lainnya [10]. Selain itu, ada yang menjabarkan pengertian e-learning lebih luas lagi. Sebenarnya materi e-learning tidak harus di distribusikan secara on-line baik melalui jaringan lokal maupun intemet. Interaksi dengan menggunakan internetpun bisa dijalankan secara on-line dan real-time ataupun recara off-line atau archieved. Distribusi secara offline menggunakan media CD/DVD pun termasuk pola e-learning. Dalam hal ini aplikasi dan materi belajar di kembangkan sesuai kebutuhan dan di distribusikan melalui media CD/DVD, selanjutnya pembelajar dapat memanfatkan CD/DVD tersebut dan belajar di tempat dimana dia berada. [11]

Menggunakan materi pembelajaran untuk dipelajari secara mandiri (self learning materials). Materi pembelajaran dapat disimpan di komputer sehingga dapat diakses oleh guru dan siswa kapan saja dan di mana saja bila yang bersangkutan memerlukannya. Memanfaatkan komputer untuk proses pembelajaran dan juga untuk mengetahui hasil kemajuan belajar, atau administrasi pendidikan serta untuk memperoleh informasi yang banyak dari berbagai sumber informasi.

\section{Manfaat E-learning}

E-learning mempermudah interaksi antara peserta didik dengan bahan/materi pelajaran. Peserta didik dapat saling berbagi informasi atau pendapat mengenai berbagai hal yang menyangkut pelajaran atau kebutuhan pengembangan diri peserta didik. Selain itu, guru dapat menempatkan bahanbahan belajar dan tugas-tugas yang harus dikerjakan oleh peserta didik di tempat tertentu di dalam web untuk di akses oleh peserta didik. Sesuai dengan kebutuhan, guru dapat pula memberikan kesempatan kepada peserta didik untuk mengakses bahan belajar tertentu maupun soal-soal ujian yang hanya dapat diakses oleh peserta didik sekali saja dan dalam rentangan waktu tertentu pula. Secara lebih rinci, manfaat e-learning dapat dilihat dari 2 (dua) sudut, yaitu dari sudut peserta didik dan guru :

\section{Sudut peserta didik}

Dengan kegiatan e-learning dimungkinkan berkembangnya fleksibilitas belajar yang tinggi. Menurut Brown, (dalam Wena) ini dapat mengatasi siswa yang: 
1)Belajar di sekolah-sekolah kecil di daerah-daerah miskin untuk mengikuti mata pelajaran tertentu yang tidak dapat diberikan oleh sekolahnya, 2)Mengikuti program pendidikan keluarga di rumah (home schoolers) untuk mempelajari materi yang tidak dapat diajarkan oleh orang tuanya, seperti bahasa asing dan ketrampilan di bidang komputer, 3)Merasa phobia dengan sekolah atau peserta didik yang di rawat di rumah sakit maupun di rumah, yang putus sekolah tapi berminat melanjutkan pendidikannya, maupun peserta didik yang berada di berbagai daerah atau bahkan yang berada di luar negeri, dan 4)Tidak tertampung di sekolah konvensional untuk mendapatkan pendidikan [12].

\section{Guru}

Menurut soekartawi beberapa manfaat yang diperoleh guru adalah bahwa guru dapat : 1)Lebih mudah melakukan pemutakhiran bahan-bahan yang menjadi tanggung jawabnya sesuai dengan tuntutan perkembangan keilmuan yang terjadi, 2)Mengembangkan diri atau merakukan penelitian guna peningkatan wawasannya karena waktu luang yang dimiliki relatif lebih banyak, 3)Mengontrol kegiatan belajar peserta didik. Bahkan guru juga dapat mengetahui kapan peserta didiknya belajar, topik apa yang dipelajari, berapa lama sesuatu topik dipelajari, serta berapa kali topik tertentu dipelajari ulang, 4)Mengecek apakah peserta didik telah mengerjakan soal-soal latihan setelah mempelajari topik tertentu, dan 5)Memeriksa jawaban peserta didik dan memberitahukan hasilnya kepada peserta didik.

Selain itu, manfaat e-rearning dengan penggunaan internet, khususnya dalam pembelajaran jarak jauh antara lain :

1) Guru dan siswa dapat berkomunikasi dengan mudah dan cepat melalui fasilitas internet tanpa dibatasi oleh tempat, jarak dan waktu. Secara regular atau kapan saja kegiatan berkomunikasi bisa dilakukan.

2) Guru dan siswa dapat menggunakan materi pembelajaran yang ruang lingkup (scope) dan urutan (sekuensnya) sudah sistematis terjadwal melalui internet.

3) Dengan e-learning dapat manjelaskan materi pembelajaran yang sulit dan rumit menjadi mudah dan sederhana. Selain itu, materi pembelajaran dapat disimpan dikomputer, sehiagga siswa dapat mempelajari kembali atau mengulang materi pembelajaran yang telah dipelajarinya setiap saat dan dimana saja sesuai dengan keperluannya.

4) Mempermudah dan mempercepat mengakses atau memperoleh banyak informasi yang berkaitan dengan materi pembelajaran yang dipelajarinya dari berbagai sumber informasi dengan melakukan akses di internet.

5) Internet dapat dijadikan media untuk melakukan diskusi antara guru dengan siswa, baik untuk seorang pembelajar, atau dalam jumlah pembelajar terbatas, bahkan missal.
6) Peran siswa rnenjadi lebih aktif mempelajari materi pembelajaran, memperoleh ilmu pengetahuan atau informasi secara mandiri, tidak mengandalkan pemberian dari guru, disesuaikan pula dengan keinginan dan minatnya terhadap materi pembelajaran.

7) Relatif lebih efisien dari segi waktu, tempat dan biaya.Bagi pembelajar yang sudah bekerja dan sibuk dengan kegiatannya sehingga tidak mempunyai waktu untuk datang ke suatu lembaga pendidikan maka dapat mengakses internet kapanpun sesuai dengan waktu luangnya.

8) Dari segi biaya, penyediaan layanan internet lebih kecil biayanya disbanding harus membangun ruangan atau kelas pada lembaga pendidikan sekaligus memeliharanya, serta menggaji para pegawainya.

9) Memberikan pengalaman yang menarik dan bermakna bagi siswa karena dapat berinteraksi langsung, sehingga pemahaman terhadap materi akan lebih bermakna pula (meaningfull), mudah dipahami, diinga dan mudah pula untuk diungkapkan.

10) Kerja sama dalam komunitas online yang memudahkan dalam transfer informasi dan melakukan suatu komunikasi sehingga tidak akan kekurangan sumber atau materi pembelajaran.

11)Administrasi dan pengurusan terpusat sehingga memudahkan dalam melakukan akses atau dalam operasionalnya.

12)Membuat pusat perhatian dalam pembelajaran. [13]

\section{Fungsi E-Learning}

Setidaknya ada 3 (tiga) fungsi pembelajaran elektronik terhadap kegiatan pembelajaran di dalam kelas (classroom instruction), yaitu [11] :

\section{Suplemen (tambahan)}

Dikatakan berfungsi sebagai suplemen, apabila peserta didik mempunyai kebebasan memilih, apakah akan memanfaatkan materi pembelajaran elektronik atau tidak. Dalam hal ini, tidak ada kewajiban/keharusan bagi peserta didik untuk mengakses materi pembelajaran elektronik. Sekalipun sifatnya opsional, peserta didik yang memanfaatkannya tentu akan memiliki tambahan pengetahuan atau wawasan.

\section{Komplemen (pelengkap)}

Dikatakan berfungsi sebagai komplemen, apabila materi e-learning diprogramkan untuk melengkapi matei pembelajaran yang diterirna siswa di dalam kelas [14] Sebagai komplemen berarti materi e-learning diprogramkan untuk menjadi materi enrichment (pengayaan) atau remedial bagi peserta didik di dalam mengikuti kegiatan pembelajaran konvensional. sebagai enrichment, apabila peserta didik dapat dengan cepat menguasai/memahami materi pelajarun yang disampaikan guru secara tatap muka diberikan kesempatan untuk mengakses materi e-learning yang memang secara khusus dikembangkan untuk mereka. Tujuannya agar semakin memantapkan tingkat penguasaan peserta didik terhadap 
materi plajaran yang disajikan guru di kelas. Sebagai remedial, apabila peserta didik mengalami kesulitan dalam memahami materi petajaran yang disampaikan guru secara tatap muka dikelas. Tujuannya agar peserta didik semakin lebih mudah memahami materi pelajaran yang disajikan guru di kelas.

\section{Substitusi (pengganti)}

Tujuan dari e-learning sebagai pengganti kelas konvensional adalah agar peserta didik dapat secara fleksibel mengelola kegiatan perkuliahan sesuai dengan waktu dan aktivitas lain sehari-hari. Ada 3 (tiga) alternatif model kegiatan pembelajaran yang dapat diikuti peserta didik: 1)Sepenuhnya secara tatap muka (konvensional), 2)Sebagian secara tatap muka dan sebagian lagi melalui internet, atau bahkan 3)Sepenuhnya melalui internet.

Faktor yang Perlu Dipertimbangkan dalam Memanfaatkan E-learing untuk pembelajaran jarak jauh adalah memilih internet untuk kegiatan pembelajaran. Memilih internet ini ada beberapa tahap yang harus dilakukan yaitu :

1. Analisis kebutuhan (need analysis)

Pemanfaatan e-learning sangat tergantung pada pengguna dalam memandang atau menilai e-learning tersebut. Digunakannya teknologi terscbut jika e-learning itu sudah merupakan kebutuhan. Untuk menentukan apakah seseorang ataulembaga pendidrkan membutuhkan atau tidak e-learning itu, maka diperlukan analisis kebutuhan. Analisis kebutuhan ini untuk menjawab pertanyaan- pertanyaan yang muncul, yaitu apakah fasilitas pendukungnya sudah memadai, apakah didukung oleh dana yang memadai; dan apakah ada dukungan dari pembuat kebijakan. Jika berdasarkan analisis kebutuhan itu diputuskan bahwa e-learning diperlukan, maka perlu membuat studi kelayakan (fasibilitystudy). Ada beberapa komponen penilaian dalam studi kelayakan yang perlu dipertimbangkan, antara lain: a). Secara teknis, apakah jaringan internet bisa dipasang beserta infrasruktur pendukungnya, sepeti jaringan komputer, instalasi listrik, saluran telepon, dan sebagainya. b). Sumber daya manusianya yang memiliki pengetahuan dan kemampuan atau ketetampilan (skill dan knowledg) yang secara teknis bisa mengoperasikanny a. c).Secara ekonomis apakah kegiatan vang dilakukan dengan e-learning ini menguntungkan atau tidak, apakah akan membutuhkan biaya yang besar atau kecil. d). Secara sosial, apakah sikap (attitude) masyarakat dapat menerimanya atau menolak terhadap penggunaan e-learning sebagai bagian dari teknologi dan omunikasi. Untuk itu perlu diciptakan sikap (attitude) yang positif terhadap e-learning, khususnya. Dan teknologi informadi dan komunikasi pada umumnya, agar bias mengerti potensi dan dampaknya bagi pembelajar dan masyarakat.

Syarat-Syarat pemanfaatan E-Learning Menurut Newsletter of ODLQC, 2001. yarat-syarat kegiatan pembelajaran elektronik (e-learning) adalah :
1. Kegiatan pembelajaran dilakukan melalui pemanfaatan jaringan dalam hal ini internet.

2. Tersedianya dukungan layanan belajar yang dapat dimanfaatkan oleh peserta belajar, misalnya CDROM atau bahan cetak

3. Tersedianya dukungan layanan tutor yang dapat membantu peserta belajar apabila mengalami kesulitan.

4. Adanya lembaga yang menyelenggarakan/mengelola kegiatan e- learning.

5. Adanya sikap positif pendidik dan tenaga kependidikan terhadap teknologi komputer dan internet

6. Adanya rancangan sistem pembelajaran yang dapat dipelajarildiketahui oleh setiap peserta belajar

7. Adanya sistem evaluasi terhadap kemajuan atau perkembangan belajar peserta didik

8. Adanya mekanisme umpan balik yang dikembangkan oleh lembaga penyelenggara.

Berbeda dengan yang telah diungkapkan di atas, dalam Nurfalah, lebih menyoroti dari tenaga-tenaga ahli yang perlu ada untuk "menghidupkan" sebuah e-learning adalah [15] : a)subject Matter Expert (sME), merupakan nara sumber dari pembelaiaran yang disampaikan. b)Instructional Designer (ID), bertugas untuk secara sistematis mendesain materi dari SME menjadi materi elearning dengan memasukkan metode pengajaran agar materi menjadi lebih interaktif, lebih mudah, dan lebih menarik untuk dipelajari. c)Graphic Designer (GD), bertugas untuk mengubah materi teks menjadi bentuk grafis dengan gambar, wama, dan layout yang enak dipandang, efektil dan menarik untuk dipelajari. Learning Management system (LMS), bertugas mengelola sistem di website yang mengatur lalu lintas interaksi antara instruktur dengan siswa, antarsiswa dengan siswa lainnya, serta hal lain yang berhubungan dengan pembelajaran, seperti tugas, nilai, dan peringkat ketercapaian belajar siswa.

Model Pembelajaran E-learning Dalam implementasi pembelajaran, terdapat model penerapan e-learning yang bisa digunakan,yaitu :

\section{Selective Model Model}

Selektif ini digunakan jika jumlah computer di sekolah sangat terbatas (misalnya hanya ada satu unit computer). Di dalam model ini, guru harus memilih salah satu alat atau media yang tersedia yang dirasakan tepat untuk menyampaikan bahan pelajaran. Jika guru menemukan bahan e-leaming yang bermutu dari internet, maka dengan terpaksa guru hanya dapat menunjukkan bahan pelajaran tersebut kepada siswa sebagai bahan demonstrasi saja. Jika terdapat lebih dari satu computer di sekolah / kelas, maka siswa harus diberi kesempatan untuk memperoleh pengalaman langsung.

2. Sequential Model

Model ini di gunakan jika jumlah computer di sekolah / kelas terbatas (misalnya hanya dua atau tiga unit computer). para siswa dalam kelompok kecil secara 
bergiliran menggunakan computer untuk mencari sumber pelajaran yang dibutuhkan. Siswa menggunakan bahan elearning sebagai bahan rujuakan atau untuk mencari informasi baru.

\section{Static Station Model}

Model ini digunakan jika jumlah computer di sekolah / kelas terbatas, sebagaimana halnya dalam sequential model. Di dalam model ini, guru mempunyai beberapa sumber belajar yang berbeda untuk mencapai tujuan pembelajaran yang sama. Bahan e-leaming digunakan oleh satu atau dua kelompok siswa untuk mencapai tujuan pembelajaran yang telah ditetapkan. Kelompok siswa lainya menggunakan sumber belajar yang lain untuk mencapai tujuan pembelajaran yang sama.

4. Laboratory Model

Model ini di gunakan jika tersedia sejumlah computer di sekolah / laboratorium yang dilengkapi dengan jaringan internet, dimana siswa dapat mengguunakannya secara lebih leluasa (satu siswa satu computer).

Dalam hal ini, bahan e-learning dapat digunakan sebagai bahan pembelajaran mandiri Setiap model elearning yang dapat digunakan dalam pembelajaran diatas masing-masing mempunyai kekuatan dan kelemahanPemilihannya tergantung infrastruktur telekomunikasi dan peralatan yang tersedia disekolah. Bagaimanapun upaya pernbelajaran dengan pendekatan e-learning ini perlu terus dicoba dalam rangka mengatasi perrnasalahanpermasalahan yang dihadapi dimasa yang akan dating berkomunikasi atau berhubungan antara satu dengan yang lain seperti sesi online atau virtual classroom atau meeting. Meskipun aktivitas pembelajaran melalui perangkat eleaming menekankan system komunikasi online, tidak bearti proses ini sama sekali meniadakan unsur-unsur hubungan pedagogis antara guru dan siswa. Bilamana ini terjadi, maka dikhawatirkan proses pembelajaran menjadi kehilangan makna esensialnya. Karena pembelajaran merupakan kegiatan yang kompeherensip, mencakup berbagai dimensi baik kognitif psikomotorik dan afektif. dikemukakan beberapa pendekatan pedagogi yang diterapkan dalam e-learning,yaitu :

1. Intructional Design

Dimana pembelajaran lebih terfokus pada kurikulum yang dikembangkan dengan menitik beratkan pada pendekatan pendidikan kelompok atau guru secara perorangan.

\section{Social-constructivist}

Merupakan pendekatan pedagogi yang kebanyakan aktivitasnya dilakukan dalam bentuk forum-forum diskusi, blogs, wiki dan aktivitas-aktivitas kolaboratif online.

3. Laurillard's conversational model

Merupakan salah satu bentuk pendekatan pedagogi yang menitik beratkan pada penggunaan bentuk- bentuk diskusi langsung secara luas.

4. Cognitive Prespective,
Menitik beratkan pada proses pengembangan kognitif melalui kegiatan pembelajaran. [16]

5. Emotional prespective,

Lebih difokuskan pada pengembangan dimensidimensi emosional pembelajaran, seperti motivasi, engagement, model-model permainan, dan lain-lain.

6. Behaviour perspective,

Menitik beratkan pada keterampilan dan perilaku yang dihasilkan dari proses belajar. Model pembelajaran dalam bentuk ini misalnya bermain peran (role playing ) dan penerapannya di dalam aktivitas-aktivitas nyata lapangan.

7. Contextual perspective,

Difokuskan pada penataan factor instrumental dan social lingkungan yang dapat mendorong terjadinya proses belajar. Bentuk-bentuk nyata model ini seperti interaksi dengan orang lain, model-model kolaboratif dan sebagainya.

\section{E. Aplikasi E-learning}

Adapun jenis aplikasi e-learning dalam pembelajaran jarak jauh antara lain :

\section{Berbasis Open Source}

a. Moodle

Istilah moddle singkatan dari Modular object oriented Dynamic Learning Environment yang berarti tempat belajar yang dinamis dengan menggunakan model berorientasi pada objek atau merupakan paket lingkungan pendidikan berbasis web yang dinamis dan dikembangkan dengan konsep berorientasi pada objek. Adapun contoh moodle sebagai berikut :

\section{1) Atutor}

Aplikasi e-learning yang berbasis open source selain moodle adalah atutor. Atutor adalah Web based open source learning control management system (LCMS) di desain dengan aksessibilitas dan kemampuan adaptasi. Atutor merupakan paket software yang diproduksi untuk kegiatan belajar berbasis internet. Pengajar dapat cepat memasang, memaketkan dan mendistribusikan materi pembelajaran, dan mengadakan kursus online-nya sendiri.

2) Audio dan video conferencing serta Videobroadcasting

Audio Conferencing Audio conferencing adalah interaksi atau konferensi langsung dalam bentuk audio (suara) antar dua orang atau lebih yang berada dalam tempat berbeda, bahkan dapat melibatkan pembelajar yang banyak pada lokasi yang tersebar dan berbeda. Teknologi yang digunakan adalah sarana teiephoil. Dalam pelaksanaan audio conferencing dibutuhkan perangkat tambahan (audio conferencing bridge)yang dapat mengurangi gangguan (noise) maupun interaksi pada system.

Video Conferencing Teknologi multimedia videobroadcasting dapat memungkinkan seluruh pembelajar melihat, mendengar, dan bekerja sama secara 
langsung. Sesuai namanya, videoconferencing memberikan visualisasi secara langsung dan lengkap kepada seluruh pembelajar dengan multimedia (video, audio dan data) Videoconferencing distance learning memungkinkan interaksi antara dua orang atau lebih, dua kelas atau lebih pada tempat yang berbeda dan waktu yang bersamaan dengan menggunakan system multipoint. Interaksi terjadi antara pembelajar dengan pengajar, pembelajar dengan pembelajar lain, pembelajar dengan materi pembelajaran dan pembelajar dengan sumbersumber informasi (information resources) pada lokasi yang berbeda dan dilakukan secaralangsung (real time) dengan komunikatif seperti pada kelas konvensional yang menerapkan tatap muka langsung. Materi pembelajaran pada videoconferencing distance learning disajikan dalam bentuk suara (audio), gambar (visual), maupun teks, secara terpisah atau bersamaan (simultan). Adapun aplikasi videoconferencing dalam dunia pendidikan dan proses pembelajaran antara lain :

1) Pertemuan (meeting) Pengajar dengan pembelajar videoconferencing memberikan kemampuan untuk menjelaskan pembelajaran dengan sangat hidup dan interaktif tanpa harus menghabiskan biaya dan waktu yang banyak untuk melakukan sesuatu pada tempat yang sama.

2) Seminar jarak jauh (Teleseminar) Teleseminar adalah seminar yang diselenggarakan melalui teleconference. Teleconference ini menjangkau beberapa tempat pada waktu yang bersamaan.setiap tempat dihubungkan dengan media videoconferencing, sehingga seminar dapat diikuti oleh pembelajar dari beberapa tempat sekaligus. pembicara seminar pun dapat menyampaikan materi seminar dari mana saja selama dia memiliki akses ke system videoconferencing yang digunakan untuk teleseminar tersebut.

3) Silabus online.

4) The word wide web (WWW) Kehadiran situs web bagi suatu organisasi pada era digital dan internet sebagai pintu masuk menemukan dan mengenal untuk memperoleh informasi suatu organisasi di lingkungan dunia maya.

5) Elektronik mail (e-mail) atau surat elektronik E-mail merupakan surat elektronik yang menyediakan suatu infrastuktur komunikasi baru. E-mail umumnya digunakan untuk menukar pesan tertulis, mengirim dan menerima dari jaringan telekomunikasi seseorang. Seseorang pengguna e-mail di sediakan sebuah mailbox elektronik dengan sebuah alamat. Sebuah pesan sering kali berupa sebuah catatan atau memo. Tetapi juga berupa dokumen kerja seperti spreadsheet, atau grafik. Bentuk catatan dalam sebuah e-mail melalui penggunaan mailbox elektronik di intemet, untuk memperoleh informasi.

6) Voice mail Sistem voice mail menyimpan pesan suara yang diubah dalam bentuk digital. Pesan suara dikirim dalam bentuk diktat kepada penerima telephon mailbox. Pesan suara secara digit disimpan pada keduanya dengan alat penyimpan, seperti disk magnetic. Ketika penerima mendapatkan kembali pesan dari mailbox, pesan diubah kembali pada bentuk suara asli. Pesan suara diatur dengan menekan serangkaian tombol telephon. Penerima pesan dapat mengulangi atau meneruskan pesan atau mengirimkan melalui mailbox lain.

7) Telekkonferensi dan system pertemuan elektronik h)Pengirim pesan kilat (instant messenger) Pengirim pesan kilat (instant messenger) berfungsi untuk memudahkan berkomunikasi tidak terbatas waktu, ruang dan orang, dilakukan kapan saja, dimana saja, dengan siapapun. Disebut pesan kilat karena pesan dikirim hanya hitungan detik dan dapat langsung terbalas. Bentuk pesan yang dikirim dapat berupa teks, suara atau video.

Videobroadcasting merupakan salah satu teknologi e-learning interaktif yang bersifat satu arah (komunikasi linear). Penggunaan program e-learning dengan program videobroadcasting lebih banyak digunakan dibandingkan dengan audio conferencing.

Hal ini trejadi karena sifat videobroadcasting yang audio visual. Dalam prinsip belajar diungkapkan bahwa belajar akan lebih berhasil jika melibatkan banyak indera. Sasaran pesertanya dalam jumlah yang besar (massal) dan menyebar (dispersed). sebagai media transaksinya umumnya menggunakan media satelit. Pembelajar mengikuti program pembelajaran melalui videobroadcasting dengan cara melihat dan mendengar pesawat televise yang terhubung kestasiun (broadcaster) tertentu melalui antenna penerima biasa atau antenna parabola yang dilengkapi decoder khusus.

Sertifikat pada e-learning Penggunaan e-learning membutuhkan jaminan akan kerahasiaan informasi (confidentiality), keutuhan dan keasrian informasi (integrity), keabsahan pengiriman informasi (authentication) dan pengakuan terhadap informasi yang dikirim sehingga tidak ada data yang disangkal, hal ini merupakan syarat yang mutlak dalam system e-learning. E-learning hanya digunakan oleh orang yang berhak. Namun, masih banyak kendala dan tantangan yang perlu mendapatkan perhatian. Pada system e-learning seringkali terjadi penyalahgunaan sehingga dapat mencemarkan nama baik seseorang atau penyelenggara program e-learning. Untuk menghindari penyalagunaan itu, seperti pemalsuan, maka digunakan senifikat digital dengan memanfaatkan infrastruktur kunci public,certification Authority (CA) adalah sebuah lembaga atau badan yang bertanggung jawab terhadap pengoperasian infrastruktur kunci public dan pengelolaan sertifikat digital.

\section{F. Kelebihan dan Kelemahan E-learning}


Kelebihan E-Learning e-learning dapat dengan cepat diterima dan kemudian diadopsi adalah karena memiliki kelebihan/keunggulan sebagai berikut : [17]

1. Pengurangan biaya

2. Fleksibilitas. Dapat belajar kapan dan dimana saja, selama terhubung dengan intemet.

3. Personalisasi. Siswa dapat belajar sesuai dengan kemampuan belajar mereka.

4. Standarisasi. Dengan e-learning mengatasi adanya perbedaan yang berasal dari guru, seperti : cara mengajarnya, materi dan penguasaan materi yang berbeda, sehingga memberikan standar kualitas yang lebih konsisten.

5. Efektivitas. Suatu studi oleh J.D Fletcher menunjukkan bahwa tingkat retensi dan aplikasi dari pelajaran melalui metode e-learning meningkat sebanyak $25 \%$ dibandingkan pelatihan yang menggunakan cara tradisional

6. Kecepatan. Kecepatan distribusi materi pelajaran akan meningkat, karena pelajaran tersebut dapat dengan cepat disampaikan melalui internet.

Sedangkan menurut Bates dan Wulf, kelebihan learning yaitu [18]:

1. Meningkatkan interaksi pembelajaran (enchance inter activity)

Pembelajaran jarak jauh online yang dirancang dan dilaksanakan secara cermat dapat meningkatkan kadar interaksi pembelajaran antara siswa dengan materi pembelajaran, siswa dengan guru, dan antara siswa dengan siswa lainnya. Siswa yang terpisah dari siswa lainnya dan juga terpisah dari pengajar akan merasa lebih leluasa atau bebas mengungkapkan pendapat atau mengajukan pertanyaan karena tidak ada siswa lainnya yang secara fisik mengamatinya.

2. interaksi pembelajaran dimana dan kapan saja (time and placeflexibility)

Siswa dapat melakukan interaksi dengan sumber belajar kapan saja sesuai dengan ketersedianan waktunya dan dimanapun dia berada, karena sumber belajar sudah dikemas secara elektronik dan tersedia untuk di akses oleh siswa melalui online learning [19]. Begitu pula dengan tugas-tugas kegiatan pembelajaran, dapat diserahkan kepada pengajar begitu selesai dikerjakan, tanpa harus menungu sampai ada janji untuk bertemu dengan pengajar, dan tidak perlu menunggu sampai ada waktu luang pengajar untuk mendiskusikan hasil pelaksanaan tugas apabila dikehendaki.

3. Memiliki jangkauan yang lebih luas (potential to reoch a global audience)

Pembelajaran jarak jauh online yang fleksibel dari segi waktu dan tempat, menjadikan jumlah siswa yang dapat dijangkau kegiatan pembelajaran melalui online learning semakin banyak dan terbuka secara luas bagi siapa saja yang membutuhkannya. Ruang, tempat dan waktu tidak lagi menjadi hambatan. Siapa saja, dimana saja, dan kapan saja, seorang dapat belajar melalui interaksinya dengan sumber belajar yang telah dikemas secara elektronik dan siap diakses melalui online learning.

4. Mempermudah penyempurnaan dan penyimpanan materi pembelajaran (easy updating of content as well as archivable capabilities)

Fasilitas yang tersedia dalam teknologi online learning dan berbagai software yang terus berkembang turut membantu mempermudah penembangan materi pembelajaran elektronik.

Demikian penyempurnaan atau pemutaakhiran materi pembelajaran yang telah dikemas dapat dilakukan secara periodic dengan cara yang lebih mudah sesuai dengan tuntutan perkembangan keilmuannya.

Disamping itu, pemutaakhiran penyajian materi pembelajaran dapat dilakukan, baik yang didasarkan atas umpan balik dari siswa maupun atas hasil penilaian guru selaku penanggung jawab atau Pembina materi pembelajaran.

\section{G. Kelemahan Atau Kekurangan E-Learning}

Walaupun demikian pemanfaatan internet untuk pembelajaran atau e-learning juga tidak terlepas dari berbagai kekurangan antara lain:

1. Kurangnya interaksi antara guru dan siswa atau bahkan antar siswa itu sendiri. Kurangnya interaksi ini bisa memperlambat terbentuknya volues dalam proses belajar dan mengajar.

2. Kecenderungan mengabaikan aspek akademik atau aspek sosial dan sebaliknya mendorong tumbuhnya aspek bisnis.

3. Proses belajar dan mengajamya cenderung ke arah pelatihan bukan pendidikan yang lebih menekankan pada aspek pengetahuan atau psikomotor dan aspek afektif.

4. Berubahnya peran guru dari yang semula menguasai teknik pembelajaran konvensional, kini juga dituntut menguasai teknik pembelajaran yang menggunakan internet.

5. Siswa yang tidak mempunyai motivasi belajar tinggi cenderung gagal

6. Tidak semua tempat tersedia fasilitas internet (mungkin hal ini berkaitan dengan masalah tersedianya listrik, telepon ataupun komputer).

7. Keterbatasan ketersediaan softwere (perangkat lunak) yang biayanya masih relatif mahal.

8. Kurangnya tenaga yang mengetahui dan memiliki keterampilan bidang internet dan kurangnya penguasaan bahasa komputer.

Disisi lain metode e-learning juga mempunyai Kendala atau hambatan dalam penyelenggaraannya, yaitu [20] :

1. Investasi. Walaupun e-learning pada akhirnya dapat menghemat biaya pendidikan, akan tetapi memerlukan investasi yang sangat besar pada permulaannya.

2. Budaya. Pemanfaatan e-learning membutuhkan budaya belajar mandiri dan kebiasaan untuk belajar atau mengikuti pembelajaran melalui komputer. 
3. Teknologi dan infrastruktur. E-learning membutuhkan perangkat komputer, jaringan handal, dan teknologi yang tepat. Desain materi. Penyampaian materi melalui e-learning perlu dikemas dalam bentuk yang learnercentric. Saat ini masih sangat sedikit instructional designer yang berpengalaman dalam membuat suatu paket pelajaran e-learning yang memadai.

\section{METODE PENELITIAN}

Jenis penelitian yang digunakan adalah studi literatur. Metode studi literatur adalah serangkaian kegiatan yang berkenaan dengan metode pengumpulan data pustaka, membaca dan mencatat, serta mengelolah bahan penelitian [21].

Studi kepustakaan merupakan kegiatan yang diwajibkan dalam penelitian, khususnya penelitian akademik yang tujuan utamanya adalah mengembangkan aspek teoritis maupun aspek manfaat praktis. Studi kepustakaan dilakukan oleh setiap peneliti dengan tujuan utama yaitu mencari dasar pijakan / fondasi utnuk memperoleh dan membangun landasan teori, kerangka berpikir, dan menentukandugaan sementara atau disebut juga dengan hipotesis penelitian. Sehingga para penelitidapat menggelompokkan, mengalokasikan mengorganisasikan, dan menggunakan variasi pustaka dalam bidangnya.

Dengan melakukan studi kepustakaan, para peneliti mempunyai pendalaman yang lebih luas dan mendalam terhadap masalah yang hendak diteliti. Melakukan studi literatur ini dilakukan oleh peneliti antara setelah mereka menentukan topik penelitian dan ditetapkannya rumusan permasalahan, sebelum mereka terjun ke lapangan untuk mengumpulkan data yang diperlukan. [22]

\section{HASIL DAN PEMBAHASAN}

Keberhasilan pembelajaran dalam suatu mata kuliah ditentukan beberapa aspek diantaranya adalah guru/pendidik mampu merancang dan merencanakan strategi, media, metode dan bahan ajar guna tercapainya suatu pembelajaran yang interaktif dan komunikatif. Penelitian terkait pemanfaatan penggunaan Google classroom sebelumnya sudah pernah ada seperti yang telah dibahas pada pendahuluan dan hasilnya adalah Google classroom. Dalam penelitian yang dilakukan penulis saat ini, hasilnya tidak jauh berbeda karena sama-sama memanfaatkan Google classroom sebagai sarana kegiatan pembelajaran. Hasil ini didapatkan melalui proses observasi (pengamatan) dan wawancara kepada siswa dan kajian literatur.

\section{A. Google Classroom}

Google Classroom memungkinkan kegiatan belajar mengajar menjadi lebih produktif dan bermakna dengan menyederhanakan tugas, meningkatkan kolaborasi, dan membina komunikasi. Pengajar dapat membuat kelas, memberikan tugas, mengirim masukan, dan melihat semuanya di satu tempat. Sekolah dan lembaga nonprofit mendapatkan Google Classroom sebagai layanan inti G Suite for Education dan G Suite for Nonprofits secara gratis. Setiap orang yang memiliki akun Google pribadi juga dapat menggunakan Classroom secara gratis.

\section{B. Fungsi Google Classroom}

Google Classroom adalah alat berbasis web gratis yang dikembangkan oleh Google. Saat itu diperkenalkan pada 12 Agustus di tahun 2014. Aplikasi ini digunakan oleh para guru dan siswa, untuk berbagi file di antara mereka. Di Google Classroom, guru dapat membuat tugas untuk siswa, dan juga dapat mengumpulkan tugas dari mereka. Baik guru dan siswa dapat bekerja tanpa menggunakan kertas dalam aplikasi ini. Berikut ini beberapa hal yang bisa dilakukan saat belajar secara daring (online) dengan Google Classroom:

a. Berbagi materi pelajaran/silabus

b. Memberikan/mengirimkan tugas

c. Mengadakan ujian/kuis Tanya jawab secara interaktif

d. Melihat tugas mendatang lewat Google Calendar

Selain berbagai manfaat di atas, Google Classroom cocok dijadikan opsi untuk belajar online karena platform ini gratis, bisa dijangkau siapa saja yang menggunakan smartphone, dan relatif aman.

\section{Fitur Google Classroom}

Google Classroom dapat disiapkan dengan mudah. Pengajar dapat menyiapkan kelas dan mengundang siswa serta asisten pengajar. Di halaman Tugas Kelas, mereka dapat berbagi informasi-tugas, pertanyaan, dan materi. Dengan Google Classroom, pengajar dapat menghemat waktu dan kertas. Mereka dapat membuat kelas, memberikan tugas, berkomunikasi, dan melakukan pengelolaan, semuanya di satu tempat. Google Classroom juga menawarkan pengelolaan yang lebih baik. Siswa dapat melihat tugas di halaman Tugas, di aliran kelas, atau di kalender kelas. Semua materi kelas otomatis disimpan dalam folder Google Drive.

Selain itu, Google Classroom memungkinkan alur komunikasi antara pengajar dengan murid atau antar-murid lebih efektif. Pengajar dapat membuat tugas, mengirim pengumuman, dan memulai diskusi kelas secara langsung. Siswa dapat berbagi materi antara satu sama lain dan berinteraksi dalam aliran kelas atau melalui email. Pengajar juga dapat melihat dengan cepat siapa saja yang sudah dan belum menyelesaikan tugas, serta langsung memberikan nilai dan masukan real-time. Yang tak kalah penting, Google Classroom terjangkau dan aman yang disediakan gratis untuk sekolah, lembaga nonprofit, dan perorangan serta tidak berisi iklan dan tidak pernah menggunakan konten pengguna atau data siswa untuk tujuan periklanan.

\section{Perangkat yang mendukung}

Google Classroom dapat diakses menggunakan internet di komputer dengan browser apa pun, seperti Chrome, Firefox, Internet Explorer, termasuk Safari. Secara umum, Google Classroom mendukung rilis browser utama secara berkelanjutan. 
Dengan kata lain, tidak perlu instalasi lantaran Google Classroom berbasis website. Akan tetapi, instalasi diperlukan bila mengakses Google Classroom melalui perangkat bergerak, lantaran juga tersedia untuk perangkat seluler berbasis Android dan Apple.

\section{E. Cara membuat Google Classroom}

Masuk ke aplikasi Google Classroom atau akses lewat peramban di PC Anda.

1. Klik Get Started, dan pilih alamat surel (email) Google yang ingin digunakan untuk bergabung di Google Classroom.

2. Tekan tanda plus (+) di pojok kanan.

3. Ada dua pilihan, yaitu Join Class dan Create Class. Pilih Create Class.

4. Ada dua pilihan role, yaitu teacher/student. Anda bisa memilih salah satunya.

5. Isi kolom class name, section, subject, dan room.

6. Setelah kelas dibuat, Google Classroom akan otomatis generate class code. Anda bisa membagikan class code ini kepada para murid agar bisa Join Class.

7. Pada bagian Classwork, Anda bisa mengunggah materi, memberikan tugas, atau mengadakan kuis.

8. Agar lebih mudah dan hemat waktu, pertanyaan kuis tidak perlu diketik satu per satu di bagian question/pertanyaan. Jadikan satu file, kemudian unggah dengan klik Add.

9. Jangan lupa tetapkan skor maksimum yang bisa didapat pelajar dan tenggat waktu (due).

10. Kemudian klik Assign.

11. Lakukan hal yang sama untuk memberikan tugas berupa daftar pertanyaan. Jadikan satu file, kemudian unggah dengan klik Add.

12. Jangan lupa tetapkan skor maksimum yang bisa didapat pelajar dan tenggat waktu (due).

13. Kemudian klik Ask.

Demikian cara mudah membuat Google Classroom dan menggunakannya untuk proses belajar mengajar.

\section{F. Keunggulan Google Classroom}

Bagi Anda yang sudah menggunakan Google Classroom, tentu Anda merasakan sekali manfaat dan keunggulan aplikasi ini dibanding aplikasi lain :

\section{Simple}

Google merancang aplikasi Google Classroom dengan integrasi yang sangat sederhana bersama $G$ suite untuk pendidikan, sehingga dengan teknologi ini tenaga pendidik bisa fokus menjalankan tugasnya sebagai tenaga pendidik.

\section{Aman}

Selain itu, Google juga menjamin tingkat keamanan yang tinggi ketika menggunakan aplikasi Google Classroom sebab layanan ini terintegrasi dengan layanan Gmail yang reputasinya sangat baik dalam hal keamanan. Teknologi ini juga berfungsi sebagai media penyimpanan atau arsip digital bagi peserta didik atau tenaga pendidik yang apabila sewaktu-waktu dibutuhkan, bisa diakses kapanpun dan dimanapun.

3. Integrasi Luas

Google Classroom juga terintegrasi dengan beberapa aplikasi pembelajaran lainnya besutan Google lainnya, seperti classcraft, Pear Deck, Quizizz, Tynker, Kami, dan Little SIS. Kolaborasi antara Google Classroom dan aplikasi tersebut akan sangat membantu tenaga pendidik dalam memberikan materi pembelajarannya.

\section{Lintas Platform}

Keunggulan selanjutnya adalah aplikasi ini bisa diakses di PC (personal computer) atau smartphone. Sehingga tenaga pendidik maupun peserta didik bisa belajar, mengerjakan tugas, dan melihat pengumuman bisa dimanapun tanpa harus bertatap muka. Sehingga sangat efisien dalam menyampaikan materi pembelajaran, tugas dan pengumuman.

\section{Mudah Digunakan}

Keunggulan selanjutnya adalah penggunaannya yang sangat friendly. Mulai dari pembuatan kelas baru sampai dengan personalisasi kelas tersebut. Semua bisa dikerjakan dengan langkah yang sangat sederhana.

Sehingga tenaga pendidik bisa fokus dengan tujuannya membuat kelas tersebut. Tenaga pendidik tidak disibukkan dengan rumitnya personalisasi dari sebuah aplikasi yang mereka gunakan.

Selain itu, Google Classroom juga hemat dari sisi pemakain kuota internet. Sebab, aplikasi ini fokus pada pembelajaran, baik itu dalam penyampaian materi maupun dalam pemberian tugas. Walaupun ada link materi yang dibagikan, tetapi link tersebut bisa diakses secara offline setelah peserta mengunduh materi atau tugas tersebut.

Keunggulan terakhir dari Google Classroom adalah para tenaga pendidik dan peserta didik tetap bisa berkomunikasi walaupun dalam kondisi apapun. Sebab, aplikasi Google Classroom bisa diakses di manapun dan kapanpun. Selain itu, Google Classroom juga terdapat fitur saling berkomentar untuk lebih meningkatkan komunikasi antara tenaga pendidik dan peserta didik.

Selain untuk mencoba pengalaman yang lebih dalam suasana belajar daring, juga untuk lebih segera berhemat di kondisi pandemi COVID 19 ini yang semakin tidak menentu.

Pembelajaran berbasis Google Classroom.

\section{G. Perencaan Pendidik}

Pertama, pendidik mendaftar akun Google classroom melalui email berupa gmail. Setelah melakukan pendaftaran, pendidik membuat kelas sesuai kebutuhan. Dalam hal ini, penulis membuat kelas mata kuliah praktikum administrasi pendidikan sebanyak 3 kelas yaitu: kelas $6 \mathrm{C}, 6 \mathrm{D}$, dan $6 \mathrm{E}$. Setelah membuat kelas, maka selanjutnya penulis melihat kode kelas yang berbeda pada setiap kelasnya di menu kelas, dan mengirimkan kode kelas tersebut kepada para siswa pada setiap kelasnya melalui group whatshapp untuk bergabung 
dalam kelas Google classroom tersebut dengan cara memasukkan kode yang telah dibagikan penulis.

Kedua, pada saat jam pelajaran sudah dimulai, guru/pendidik melakukan absen offline dan online di Google classroom pada menu forum dengan cara melihat siapa saja yang sudah mengumpulkan tugas di hari tersebut. Dikarenakan ada beberapa tugas yang harus diselesaikan dalam satu hari, contohnya seperti menjawab soal-soal. Guru/pendidik mata pelajaran yang bersangkutan mempunyai cara absensi yang sedikit berbeda dengan cara melihat pengumpulan tugas harian oleh siswa. Siswa yang saat proses pembelajaran selalu mengerjakan dan mengumpulkan tugas, akan membuat hasil absensinya menjadi aman dan tidak ada kekurangan nilai. Adapun siswa yang tidak mengerjakan serta mengumpulkan tugas mengakibatkan nilai akhir yang diperoleh menjadi kecil. Hal itu membuktikan bahwa Google classroom dapat dengan mudah memberi data spesifik peserta didik yang sudah mengerjakan tugas atau belum, sehingga dapat mempermudah guru/pendidik dalam pengolahan nilai.

Ketiga, hasil wawancara siswa bahwa perencanaan guru/pendidik memberikan stimulus dan reward kepada siswa menunjukkan kepedulian yang tinggi dalam mata pelajaran tersebut. Hal ini didukung guru/pendidik tersebut dengan cara selalu memberikan kata-kata motivasi untuk selalu berjuang dan belajar.

\section{H. Kesiapan Siswa}

Hasil wawancara berikutnya guru/pendidik menyampaikan kesiapan siswa untuk mengikuti perkuliahan dengan mempertimbangkan unsur kebijaksanaan. Mengingat latar belakang dan keadaan pandemi, banyak diantara pekerja yang terdampak akibat wabah covid 19 ini yang mengakibatkan siswa pun kesulitan dalam membeli kuota internet atau dengan banyaknya perkuliahan yang memakai platfom virtual yang memakai banyak kuota seperti zoom atau googlemeet.

Dengan pertimbangan hal tersebut, teknis penggunakan Google classroom itu digunakan untuk absensi KBM, pemberian materi, pemberian dan penyerahan tugas serta diskusi. Untuk pembelajaran melalui virtual guru/pendidik tersebut menggunakan googlemeet dengan waktu 10 menit di awal pembelajaran setelah itu semua siswa menggunakan akses Google classroom.

Semangat belajar Siswa sangat mempengaruhi kualitas pembelajaran. Cara guru/pendidik dalam menyemangati siswa agar tetap semangat belajar walaupun proses pembelajaran dilakukan secara daring di tengah pandemi seperti ini ialah dengan tidak memberikan tugas berat terus menerus di setiap minggunya. Seharusnya guru/pendidik terkadang diselingi dengan memberikan kuis-kuis yang menyenangkan atau dengan video-video motivasi yang diharapkan dapat mengembalikan semangat belajar Siswa.

Pembuatan materi secara menarik dan tidak membosankan juga membantu menambah semangat belajar siswa. Selain itu, guru/pendidik juga harus mempunyai energi positif dan selalu semangat. Apabila guru/pendidik sudah semangat, maka selanjutnya dapat memberikan motivasi kepada Siswa agar tetap semangat walaupun dengan keadaaan di tengah wabah COVID-19.

Siswa yang penulis temui beragam responnya ada yang selalu mengerjakan tugas di waktu hampir jatuh tempo, sampai kendala handphone yang rusak sehingga menghambat proses perkuliahan. Siswa lainnya ada yang motivasinya lebih meningkat dibandingkan dengan pembelajaran yang dilakukan secara tatap muka, dikarenakan ketertarikannya terhadap teknologi dan adanya kemudahan fitur yang disajikan oleh Google classroom. Hal itu menyebabkan siswa yang sebelumnya tidak aktif di kelas menjadi lebih aktif dan rajin saat kegiatan pembelajaran online.

\section{Penyampaian Materi}

Hasil wawancara siswa Guru/pendidik kegiatan pembelajaran menjadi jelas dengan memanfaatkan fitur-fitur yang terdapat dalam Google classroom. Alhamdullillah kegiatan pembelajaran yang di berikan melalui google classroom menyampaikan materi dengan sangat jelas, menguasai materi seputar teknis yang berkaitan dengan implementasi dan prosedural dalam perangkat pembelajaran. Hal tersebut disampaikan secara sistematis dan siswa dapat memahaminya karena menggunakan metode praktek melalui tugas yang bisa diakses dimenu penugasan. Untuk fitur yang digunakan guru/pendidik tersebut, hampir seluruhnya menggunakan fitur yang ada pada Google classroom karena sudah dikuasai.

Hasil wawancara berikutnya adalah guru/pendidik menyampaikan materi setiap pembelajaran dengan cara membagikan materi di menu materi yang ada pada Google classroom dan siswa dapat mengunduhnya dengan mudah, setelah itu didiskusikan di dalam menu Forum. Setelah diskusi menggunakan Google classroom, maka untuk pelengkap penyampaian materi dipadukan dengan zoom untuk tatap muka. Google classroom dapat menampilkan materi serta tugas dalam bentuk soal-soal, selain itu dapat mengirim materi dalam bentuk power point dan juga menyertakan link yang langsung terhubung ke youtube.

Dengan adanya googleclassroom diharapkan penggunaannya menjadi semakin efektif seiring dengan berkembangnya teknologi dan metode pembelajaran yang digunakan. [23] Guru/pendidik menyebutkan bahwa aplikasi Google classroom merupakan aplikasi yang cukup lengkap, karena sudah banyak fitur yang tersedia di dalamnya. Google classroom juga merupakan platform yang mudah dicari dan digunakan oleh siapa saja. Namun, tentu ada beberapa kendala dalam penggunaan Google classroom contohnya seperti kendala pada alat elektronik seperti handphone dan laptop ataupun kendala pada kuota, yang menyebabkan materi maupun tugas tidak dapat dilihat ataupun dikerjakan langsung oleh peserta didik karena kendala-kendala tersebut.

Dalam hal pengoperasian Google classroom, guru/pendidik pada awalnya kebingungan dalam penggunaan fitur-fiturnya. Oleh karena itu, untuk lebih memaksimalkan 
dalam penggunanan Google classroom, para guru/pendidik membutuhkan waktu agar dapat memahami berbagai macam fitur-fitur yang sudah tersedia. Siswa pun mengalami kemudahan dan kendala dalam penggunaan Google classroom. Kemudahan yang mereka alami saat menggunakan Google classroom ialah dalam hal pengerjaan tugas, karena dapat langsung dikerjakan di Google classroom tanpa perlu capek menulis catatan ataupun jawaban di buku tulis dan lembar tugas atau mengeprint tugasnya di rental sehingga membutuhkan biaya untuk print.

Kendala yang mereka rasakan sangat berbanding terbalik dari kemudahan, kendala yang mereka alami ialah terkait materi yang terkadang sulit dipahami dan hanya bisa dijelaskan secara langsung oleh guru/pendidik. Dalam hal pengoperasian Google classroom, mereka tidak mengalami kendala apapun. Karena menurut mereka apabila sering digunakan pasti semakin lama akan mahir, jadi wajar apabila diawal penggunaan aplikasi Google classroom agak sedikit kebingungan dengan cara pengoperasiannya. E-learning juga mengakibatkan siswa untuk berperan lebih aktif dalam pembelajarannya. Siswa tentunya akan berusaha untuk mencari materi dan dengan inisiatifnya sendiri [24].

Mengenai materi yang dipaparkan melalui Google classroom, guru/pendidik mengalami kemudahan dalam menyampaikan materi. Menurut kedua guru/pendidik pengampu mata kuliah praktikum administasi pendidikan, beranggapan bahwa sebagian besar materi dapat dipaparkan dengan mudah apabila bisa memanfaatkan fitur yang disediakan oleh Google classroom serta mengemas materi secara menarik. Contohnya materi yang biasanya hanya menggunakan metode ceramah pada saat tatap muka, melalui Google classroom dapat dikemas secara menarik melalui video-video pembelajaran yang sudah tersedia banyak di youtube atau guru/pendidik sendiri yang mengerjakannya.

Adapun kesulitan yang dialami oleh guru/pendidik dalam pembelajaran yang dilakukan melalui Google classroom, contohnya yang pertama ialah ketika siswa melakukan tes tertulis, siswa dapat mencopy-paste jawaban sehingga seringkali kejujuran diragukan.

Kedua, ketika siswa melakukan pembelajaran dalam Google classroom, siswa dapat mengakses aplikasi lain yang tidak diperlukan dalam pembelajaran, sehingga dapat dikatakan memecah konsentrasi siswa. Selain itu, beberapa materi ada yang dianggap sulit karena tidak adanya interaksi secara langsung (video conference) sehingga mengakibatkan guru/pendidik tidak bisa mengoreksi bacaan atau tulisan yang salah secara langsung, tingkat kewaspadaan guru/pendidik terhadap mahasiwa yang mencontek juga meningkat. Siswa juga mengalami sedikit kesulitan dalam menerima materi, dikarenakan peserta didik tidak dapat berinteraksi serta bertanya secara langsung mengenai penjelasan yang belum dipahami kecuali guru/pendidik yang bersangkutan menggunakan platform lainnya seperti zoom atau googlemeets.

Hal tersebut membuat siswa mencari alternatif sumber lain selain dari materi yang diberikan oleh guru/pendidik, misalnya dari google, youtube, brainly, dan lain-lain. Peserta didik diperbolehkan bertanya kepada guru/pendidik melalui kolom komentar di Google classroom ataupun melalui WhatsApp pribadi. Tahapan dalam pemaparan materi melalui Google classroom ialah :

1. Guru/pendidik menyiapkan materi yang akan dipelajari, materi dapat berupa ppt atau pdf serta tambahan video yang diambil dari youtube.

2. Guru/pendidik mengunggah materi tersebut ke gooogle classroom untuk dapat dipelajari oleh siswa

3. Siswa mempelajari materi tersebut dan diperbolehkan bertanya melalui kolom komentar Google classroom atau whatsapp pribadi atau group

4. Guru/pendidik memberikan tugas yang sudah dibuat melalui google formulir lalu diunggah melalui Google classroom.

5. Siswa mengerjakan tugas dan mengumpulkannya melalui Google classroom. Pemahaman siswa terhadap materi dapat dilihat melalui hasil belajarnya. Apabila hasil belajarnya bagus, maka menandakan bahwa siswa sudah memahami materi yang dipaparkan oleh guru/pendidik.

Dalam hal pemahaman materi, siswa merasa sudah cukup dengan hasil tugas yang nilainya rata-rata di atas 80 , tetapi mereka juga membutuhkan alternatif sumber lain untuk dapat lebih memahami materi yang dipaparkan yaitu dengan menggunakan zoom atau google meets yang merupakan tatap muka secara virtual.

\section{KESIMPULAN}

Berdasarkan analisis pembahasan di atas, maka dapat disimpulkan bahwa proses pembelajaran terlaksana dengan baik menggunakan Google classroom. Hal ini dikarenakan pembelejaran daring melalui Google classroom pada kdegiatan pembelajaran dapat dengan mudah diakses baik oleh guru/pendidik maupun siswa sesuai dengan kebutuhan kegiatan pembelajaran.

Pemanfaatan pembelajaran dengan menggunakan google classroom memiliki dampak yang positif dapat dilihat dari hasil belajar siswa yang semakin meningkat setiap harinya melalui tugas dan kuis. Persepsi siswa mengenai mata pelajaran yang dilakukan melalui daring menggunakan aplikasi Google classroom yaitu siswa merasa senang menggunakan Google classroom karena mudah dan guru/pendidik tidak memberatkan dengan memberikan banyak tugas, Google classroom bersifat fleksibel yaitu mudah di akses dimana saja dan kapan saja, terkendala akses internet dari tidak adanya jaringan data maupun smartphone yang digunakan sebagai pendukung semua siswa untuk pelaksanaan pembelajaran e-learning.

Dengan demikian, kesimpulan penggunaan aplikasi Google classroom pada mata pelajaran terbukti efektif karena dapat meningkatkan hasil belajar siswa melalui perencanaan, proses, hasil dan evaluasi belajar siswa.

\section{Saran}


Kerja sama dengan orang tua menjadi hal yang penting demi suksesnya pendidikan anak-anak. Intervensi biaya dari orang tua, kerja sama dengan pihak sekolah melalui intervensi dana BOS dapat membantu mengatasi permasalahan yang dihadapi siswa.

Hambatan, solusi dan harapan dalam pembelajaran dengan menggunakan sistem daring menjadi topik yang menarik dalam masa pandemi Wabah Covid-19 ini. Meski dalam kondisi yang serba terbatas karena pandemic COVID19 tetapi masih dapat melakukan pembelajaran dengan cara daring. Hanya hal yang menjadi hambatan adalah orang tua harus menambah waktu untuk mendampingi anakanak. Sedangkan dari segi guru, guru menjadi melek teknologi dan dituntut untuk belajar banyak hal kususnya pembelajaran berbasis daring. Sistem pembelajaran daring ini dapat dijadikan sebagai model dalam melakukan pembelajaran selanjutnya.

Jaringan internet yang belum merata bahkan belum menjangkau daerah-daerah tertentu, disiasati dengan menerapkan program pembelajaran luring. Guru memanfaatkan kurir atau bahkan langsung mendatangi rumah-rumah siswa untuk melakukan pembelajaran tatap muka dengan tetap memperhatikan protokol kesehatan

\section{UCAPAN TERIMA KASIH}

Terima kasih kepada seluruh yang pihak yang berperanmemberikan kelancaran dan kemudahan dalam kegiatan dipenulisan artikel mengenai Pemanfaatan Google Classroom Sebagai Media Pembelajaran Di Masa Pandemi Covid-19. Semoga artikel ini dapat bermanfaat bagi para pendidik dan seluruh stakeholder pendidikan dalam meningkatan mutu proses pembelajaran di masa pandemi.

\section{DAFTAR PUSTAKA}

[1] E. Wicaksana, "Efektifitas Pembelajaran Menggunakan Moodle Terhadap Motivasi Dan Minat Bakat Peserta Didik Di Tengah Pandemi Covid -19," EduTeach : Jurnal Edukasi dan Teknologi Pembelajaran, vol. 1, no. 2, pp. 117-124, 2020.

[2] M. D. A Pane, "Belajar dan Pembelajaran," FITRAH: Jurnal Kajian Ilmu-Ilmu Keislaman, vol. 2, no. 3, pp. 333-352, 2017.

[3] S. b. Djamarah, Psikologi Belajar, Jakarta: Rineka Cipta, 2012.

[4] E. Nasution, "Problematika Pendidikan di Indonesia," Jurnal Fakultas Ushuluddin Dan Dakwah IAIN Ambon, vol. 1, no. 2, pp. 1-10, 2008.

[5] N. Sudjana, Media Pengajaran, Jakarta: Algesindo, Sinar Baru, 2001.

[6] C. T. Morgan, Introduction to Psychology, New York: Kogakusha: Mc Graw-Hill,, 2001.

[7] A. Suprijono, Cooperatif Learning : Teori dan Aplikasi PAIKEM., Yogyakarta: Pustaka Pelajar, 2007.

[8] Tafiardi, " Meningkatkan mutu pendidikan melalui e-learning," Jurnal: Pendidikan Penabur, vol. 4, no. 2, pp. 27-36, 2005.

[9] W. \&. H. K. Horton, E-Learning Tools and Technologies: A consumer guide for trainers, teachers, educators, and instructional designers. USA : Wiley Publishing, Inc. , 2003

[10] H. Kamarga, " Managemen E-learning : Mengelola Pengetahuan Sebagai Komoditas," Mimbar pendidikan, Jurnal Pendidikan, vol. 3, no. 2, pp. 57-68, 2001.
[11] S. Siahaan, " E-Learning (Pembelajaran Elektronik) sebagai salah satu alternatif kegiatan pembelajaran.," Jurnal Pendidikan 42, vol. 4, no. 2, pp. 78-89, 2004.

[12] M. Wena, Strategi Pembelajaran Inovatif Kontemporer, Jakarta: Bumi Aksara, 2009.

[13] M. Wijaya, " Pengembangan Model Pembelajaran e-Learning Berbasis Web dengan Prinsip e-Pedagogy dalam Meningkatkan Hasil Belajar.," Jurnal Pendidikan Penabur, vol. 19, no. 3, pp. 78-96, 2012.

[14] Silahuddin, "Penerapan E-Learning dalam Inovasi Pendidikan.," CIRCUIT: Jurnal Ilmiah Pendidikan Teknik Elektro, vol. 11, no. 1, p. 48-59. , 2015.

[15] E. Nurfalah, "Optimalisasi E-Learning berbasis Virtual Class dengan Google Classroom sebagai Media Pembelajaran Fisika.," Physics Education Research journal, vol. 9, no. 2, pp. 44-56, 2019.

[16] Munir, Kurikulum Berbasis Teknologi Informasi dan Komunikasi, Bandung: Alfabeta, 2008.

[17] Munir, "E-Learning : Membangun System Pendidikan Berbasis Dunia Maya.," Mimbar pendidikan, Jurnal pendidikan, vol. 3, no. 3, pp. 4564, 2004.

[18] S. R. Chandrawati, "Pemanfaatan E-Learning dalam Pembelajaran," Jurnal Cakrawala Kependidikan, vol. 8, no. 2, pp. 101-203, 2010.

[19] I. Purwandani, "Pengembangan Elearning Berbasis Claroline untuk Pembelajaran PTIK.," in Prosiding KNIT , Jakarta, 2016.

[20] K. Y. Tung, Pendidikan dan Riset di Internet., Jakarta: Dinastindo., 2000.

[21] Sugiyono, Metode Penelitian Pendidikan (Pendekatan Kuantitatif, Kualitatif, dan R \& D), Bandung: Alfabeta, 2010.

[22] S. Arikunto, Prosedur Penelitian Suatu Pendekatan Praktik, Jakarta: Rineka Cipta, 2018.

[23] A. Hardhono, "Potensi Teknologi Komunikasi dan Informasi dalam Mendukung Penyelenggaraan Pendidikan Jarak Jauh di Indonesia.," Jurnal Pendidikan Terbuka dan Jarak Jauh. Pusat Studi Indonesia, Lembaga Penelitian Universitas Terbuka., vol. 3, no. 1, pp. 112-126, 2002.

[24] A. H. Elyas, " Penggunaan Model Pembelajaran E-Learning Dalam Meningkatkan Kualitas Pembelajaran.," Jurnal Warta, vol. 56, no. 4, pp. 1-11, 2018. 